\title{
Site-related differences in the feeding physiology of the green mussel Perna viridis: a reciprocal transplantation experiment
}

\author{
W. H. Wong, S. G. Cheung* \\ Department of Biology and Chemistry, City University of Hong Kong, Kowloon, Hong Kong SAR
}

\begin{abstract}
Differences in the feeding physiology of the green mussel Perna viridis between 2 aquaculture sites with contrasting hydrographies in Hong Kong were demonstrated. One site, Kat O, is oceanic and characterized by low seston concentrations and high organic contents. The other, Ma Wan, is under the influence of the Pearl River Estuary, hence the water is more turbid and has a low organic content. To determine the extent to which differences in mussel feeding responses were caused by environmental factors, a reciprocal transplantation experiment between the 2 sites was undertaken. Feeding rates (clearance rate, rejection rate, absorption rate and absorption efficiency) and enzyme activities (amylase and cellulase) were determined at various times, up to 8 mo posttransplantation. Complete acclimatization of the physiological responses of transplanted mussels occured $30 \mathrm{~d}$ post-transplantation. Transplanted individuals also showed complete morphological acclimatization in terms of palp area and palp:ctenidial area ratio $150 \mathrm{~d}$ post-transplantation, with higher ratios being obtained at Kat $\mathrm{O}$, where suspended solid levels were lower, which is in contrast to other mytilids. The physiological differences between the 2 populations are thus largely environmentally induced.
\end{abstract}

KEY WORDS: Mussels $\cdot$ Perna viridis $\cdot$ Feeding rate $\cdot$ Digestive enzymes $\cdot$ Palp:ctenidial area ratio Transplantation

\section{INTRODUCTION}

Suspension-feeding bivalves living in shallow waters are exposed to large fluctuations in food supply, both in terms of composition and concentration. Variations may be associated with seasonal events such as the seasonal availability of phytoplankton, or shortterm events such as the resuspension of sediment caused by wave and/or tidal action (Bayne 1993, Navarro \& Iglesias 1993). To cope with such a variable food environment, and to optimize ingested energy, various feeding strategies have evolved in suspensionfeeding bivalves. These include regulation of feeding rates and enzymatic activities, and production of pseudofaeces (Bayne \& Newell 1983, Navarro \& Iglesias 1993). Compared with considerable scientific research on Mytilus spp. in temperate waters, much less work has been done on tropical and subtropical species (Ward \& MacDonald 1996, Hawkins et al. 1998a, Yukihira et al. 1999), particularly the warm-water species Perna viridis (L.), though it is of high ecological significance (Seed \& Richardson 1999) and has aquaculture value (Guo et al. 1999).

The green mussel Perna viridis widely distributed in the Indo-Pacific region, from the Persian Gulf to the SW Pacific longitudinally, and from southern Japan to Papua New Guinea latitudinally (Siddall 1980). It has recently been introduced into coastal areas of the western hemisphere, such as Venezuela, Trinidad, Jamaica, and Florida in the United States (Ingrao et al. 2001). It is one of 5 mussel species cultured commercially in Guangdong and other southern provinces in China (Guo et al. 1999), and is an inexpensive protein source in Southeast Asia. After China, Thailand is the 
second largest producer of mussels in Asia and $P$. viridis yields the highest net profit of any bivalve cultured in the country (Chalmermwat \& Lutz 1989). In Hong Kong, P. viridis is distributed widely, from oceanic to estuarine waters, and is a dominant subtidal species with highest densities recorded from Victoria Harbour $\left(246 \mathrm{~m}^{-2}\right)$ and Tolo Harbour $\left(>1000 \mathrm{~m}^{-2}\right)$ (Huang et al. 1985).

Reciprocal transplantation is commonly used to examine the plasticity of bivalve physiological responses, and also the extent to which measured differences in native populations may be environmentally induced (i.e. phenotypic) rather than genetically determined characteristics (i.e. genotypic) (Worrall \& Widdows 1983). This technique has been applied successfully to studying inter-site differences in feeding rates, growth, energetics and metal accumulation in mussels (Widdows et al. 1984, Kautsky et al. 1990, Tedengren et al. 1990, Okumus \& Stirling 1994, Riget et al. 1997). In one experiment, Perna viridis was transplanted from Tolo Harbour to various locations in Hong Kong, with highest and lowest growth being obtained in eastern and western waters, respectively (Cheung 1991). Such inter-site differences in growth, reproduction and energetics of $P$. viridis were reported to be largely determined by environmental factors (Lee 1986, Cheung 1991).

Spatial and temporal variations in the feeding physiology of Perna viridis were studied for $1 \mathrm{yr}$ at 2 sites in Hong Kong (Wong \& Cheung 2001a, 2003). These 2 sites, Kat $\mathrm{O}$ and Ma Wan, are located in the eastern and western waters of Hong Kong, respectively. Kat O is characterized by low seston concentrations and high organic contents. In contrast, under the influence of the Pearl River, which is the third largest river in China, Ma Wan is estuarine and characterized by high seston concentrations and lower organic contents (Morton \& Morton 1983). Feeding responses, including clearance rate, absorption rate and efficiency, and digestive enzyme activities (amylase and cellulase), were correlated with food availability (Wong \& Cheung 2001a, 2003). Inter-site differences in feeding responses, however, were still discernible. For example, pseudofaeces production was interpreted as a selective behaviour which enhances the ingestion of particulate organic matter (POM) for individuals of $P$. viridis at Ma Wan, but not at Kat $\mathrm{O}$. Such inter-site differences in feeding behaviour may be environmentally induced or caused by genetic differ- ences. Differences in allelic and genotypic frequencies have been observed between $P$. viridis populations at 2 other sites in Hong Kong, Victoria Harbour and Tolo Harbour, and among the 9 genotypic classes studied, 6 occurred more frequently in the Victoria Harbour samples, while 3 occurred more frequently in the Tolo Harbour samples (Chan 1992). In the present study, native populations of $P$. viridis at Kat $\mathrm{O}$ and $\mathrm{Ma}$ Wan (Fig. 1) were transplanted reciprocally, and the feeding responses of transplanted individuals were compared with those of native ones to determine to what extent inter-site differences are environmentally induced in the physiological responses of $P$. viridis.

\section{MATERIALS AND METHODS}

Perna viridis. Kat $O$ is located in the northeastern oceanic waters of Hong Kong, which are characterized by low total particulate matter (TPM) and high organic contents $(f)$. In contrast, Ma Wan is located in the central waters of Hong Kong and is characterized by high TPM and low $f$ values. Salinity at Ma Wan, particularly in summer, is also lower than at Kat O (Fig. 1). Feeding and absorption by Perna viridis varied with both season and site and were postulated to be the result of food availability (Wong \& Cheung 2001a, 2003). A reciprocal transplantation experiment was also undertaken at the 2 study sites. On 5 February 1998, individuals of $P$. viridis were collected from Kat $\mathrm{O}$ and separated into 2 size categories, small (S) and large (L), each containing 160 individuals. Half of each group (80 individuals) was then cultured in cages at the same site

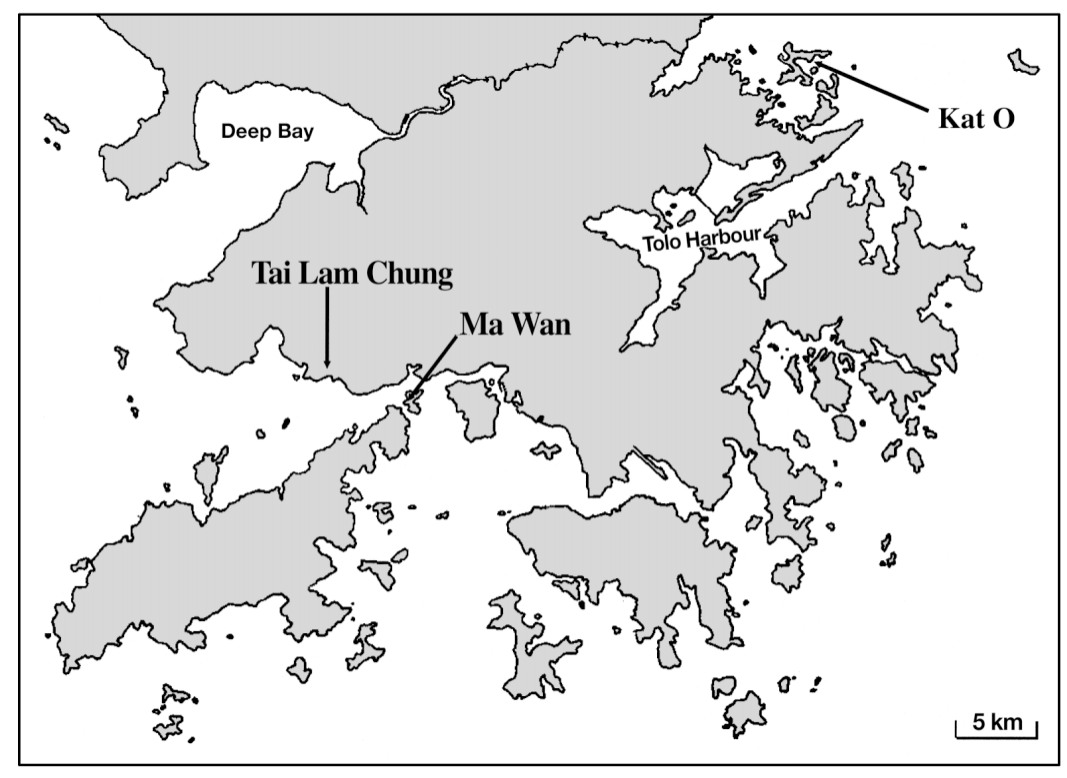

Fig. 1. Map of Hong Kong showing Kat O and Ma Wan, the experimental sites for reciprocal transplantation 
and referred to as KO. Another half was transplanted to Ma Wan on the same date and referred to as $\mathrm{KO} \rightarrow \mathrm{MW}$. On the same date, individuals of $P$. viridis were also collected from Ma Wan and divided into 2 size groups. Half of these were then cultured in cages at Ma Wan (MW), and the other half transplanted to Kat O (MW $\rightarrow \mathrm{KO}$ ). Individuals were kept out of water, but in a moist environment, for $4 \mathrm{~h}$ during transportation between the 2 sites. Native individuals were kept under the same conditions for $4 \mathrm{~h}$ before being put into experimental cages. Initial sizes among the 4 experimental groups were not significantly different for either small (1-way ANOVA, $F=0.06$, df $=3,24$, $\mathrm{p}=0.98$ ) or large individuals (1-way ANOVA, $F=1.24$, $\mathrm{df}=3,24, \mathrm{p}=0.32$ ) (see Fig. 4).

Hydrographic parameters. Temperature, salinity, dissolved oxygen and seston characteristics, and feeding responses of Perna viridis, were determined on 5 occasions at each site. These were: 15 to 20 February, 5 to 10 March, 5 to 10 May, 5 to 10 July and 5 to 10 October 1998, i.e. $\sim 10,30,90,150$ and 240 d posttransplantation, respectively.

Seston characteristics. TPM $\left(\mathrm{mg} \mathrm{l}^{-1}\right)$, POM $\left(\mathrm{mg} \mathrm{l}^{-1}\right)$, particulate inorganic matter (PIM: $\mathrm{mg} \mathrm{l}^{-1}$ ) and organic fraction of seston $(f)$ of the seawater were determined. This was done by collecting a water sample of $300 \mathrm{ml}$ at a time interval of ca. 30 min from the outflow of the empty container (control) (see 'Physiological measurements'). Each water sample was filtered onto ashed and pre-weighed $25 \mathrm{~mm}$ GF/C filters (Whatman) and rinsed with distilled water. Instead of using isotonic ammonium formate, distilled water was used to remove salts because a preliminary test showed that there was no significant difference in the results obtained by these 2 methods (Wong \& Cheung 1999). The samples were dried in an oven $\left(110^{\circ} \mathrm{C}\right.$ for $\left.24 \mathrm{~h}\right)$, weighed, and ashed in a muffle furnace $\left(450^{\circ} \mathrm{C}\right.$ for $\left.6 \mathrm{~h}\right)$ before final weighing. Thus, concentrations of TPM and PIM were measured. POM concentration was estimated by subtracting PIM from TPM. The organic content of suspended matter was computed as $f=\mathrm{POM} / \mathrm{TPM}$.

Physiological measurements. Physiological responses, which included rejection and clearance rates, and absorption efficiency and rate, were determined $\sim 10$, 30, 90, 150 and $240 \mathrm{~d}$ post-transplantation. During each visit, 7 individuals of Perna viridis from each size group of the 4 treatments were placed in separate plastic containers $(250 \mathrm{ml})$ into which natural seawater $(10 \mathrm{~cm}$ below the sea surface) was pumped from the sea via a multi-channel peristaltic pump (Wong \& Cheung 2001a, 2003). One vessel containing no mussels was used as a control to determine the characteristics of natural seawater. A preliminary experiment was undertaken to determine the optimum flow rate for the experiment. Seven individuals with shell lengths between 42 and $65 \mathrm{~mm}$ were placed in separate containers and received a continuous flow of fresh seawater. Five flow rates were tested for suitability in the experiment $\left(50,100,150,200\right.$ and $\left.250 \mathrm{ml} \mathrm{min}^{-1}\right)$, and the clearance rate at $50 \mathrm{ml} \mathrm{min}{ }^{-1}$ was found to be significantly different from the others. A flow rate of $100 \mathrm{ml} \mathrm{min}^{-1}$, therefore, was used, and the depletion of particle concentration produced by the filtering activity of $P$. viridis at this flow rate was $<40 \%$, as determined by an electronic Coulter Counter. To minimize the problem of recirculation, the position of each $P$. viridis in the chamber was adjusted such that the inflow tube of the chamber (at the bottom) was facing an individual's inhalant aperture, and exhalant apertures faced the out-flow tube (at the top) (Riisgård 1977). Individuals were left in separate trays with flowing seawater for ca. $1 \mathrm{~h}$ prior to experimentation to evacuate the gut. Subsequently, all pseudofaeces and faeces produced in the first hour were removed using an autopipette. Between 1.5 and $2 \mathrm{~h}$ later, faeces and pseudofaeces were collected separately. They can be differentiated by their appearance, in that particles in pseudofaeces are loosely held by mucus, whereas faeces are more tightly packed. As seawater used in the experiment was pumped directly from just below the sea surface where the bivalves were held, the seston collected during the feeding experiments was a good representation of the material that the bivalves had fed on ca. 6 to $9 \mathrm{~h}$ (a complete digestive cycle including both extracellular and intracellular digestive phases) prior to the experiments. The effect of tidal cycles on seston composition was minimized by undertaking the experiment during neap tides in each month, when temporal variations in seston quantity and quality were small (Wong \& Cheung 2001b).

During each site visit, feeding rates were determined for 7 individuals from each size group. A sample size of 7 was used, as it was found to be adequate for significant results in a previous study on the feeding behaviour of this species (Wong \& Cheung 1999). Faeces and pseudofaeces were collected with an autopipette and treated in the same way as the seston particles, described previously. Measured parameters included: rejection rates (in $\mathrm{mg} \mathrm{h}^{-1}$ ), as pseudofaeces of the total (RR), organic (ORR) and inorganic (IRR) particulate matter; and egestion rates (in $\mathrm{mg} \mathrm{h}^{-1}$ ), as true faeces of the total (ER), organic (OER) and inorganic (IER) particulate matter. Assuming that absorption of the inorganic matter through the digestive system is negligible, the sum of IRR and IER was considered to represent the rate of inorganic matter filtration (IFR) and, hence, clearance rates $\left(\mathrm{CR}: 1 \mathrm{~h}^{-1}\right)$ were estimated as $\mathrm{CR}$ $=$ IFR/PIM (Iglesias et al. 1996). The filtration rate (in $\mathrm{mg} \mathrm{h}^{-1}$ ) of TPM (FR) was calculated as FR $=\mathrm{CR} \times \mathrm{TPM}$ and that of $\mathrm{POM}(\mathrm{OFR})$ as $\mathrm{OFR}=\mathrm{CR} \times \mathrm{POM}$. Ingestion 
rates (in $\mathrm{mg} \mathrm{h}^{-1}$ ) of total (IR) and organic (OIR) particulate matter were estimated as IR $=\mathrm{FR}-\mathrm{RR}$ and OIR = OFR - ORR, respectively. The rate of food absorption (AR: $\mathrm{mg} \mathrm{h}^{-1}$ ) was calculated as $\mathrm{AR}=\mathrm{OIR}-\mathrm{OER}$, and absorption efficiency (AE) as AE = AR/OIR. Energy absorbed was calculated from AR using a conversion factor of $20.78 \mathrm{~J} \mathrm{mg}^{-1}$ POM (Crisp 1971).

Amylase and cellulase activities. Owing to logistic problems, enzyme activities in the digestive diverticula and crystalline style could only be determined on Days 90, 150 and 240 post-transplantation. Since amylase and cellulase activities are highest among all the carbohydrases in the digestive diverticula of Perna viridis, and lipase and protease activities are low (Teo \& Sabapathy 1990), only those of $\alpha$-amylase and cellulase were studied in the present experiment. The digestive diverticula and crystalline style were collected in situ, placed in liquid nitrogen, transported to the laboratory and stored at $-30^{\circ} \mathrm{C}$ for in vitro enzyme assays. Wet weights of the digestive diverticula and crystalline styles were recorded before enzyme assays. Either 1 digestive diverticulum or 2 crystalline styles were homogenised in cold $20 \mathrm{mM}$ phosphate buffer $(\mathrm{pH} 6.9$ and 6.5, respectively) containing $20 \mathrm{mM} \mathrm{NaCl}$ and centrifuged for $15 \mathrm{~min}(4000 \times g)$. The clear supernatants were used to determine amylase and cellulase activities using the Nelson-Somogyi method (Nelson 1944, Somogyi 1952). Standard calibration curves were determined with glucose. The substrata for the determination of amylase and cellulase were starch $(1 \%)$ and carboxymethylcellulose $(1 \%)$, respectively, and they were made up with appropriate phosphate buffers for the digestive diverticula and crystalline styles, respectively (Ibarrola et al. 1998a). Diverticula and crystalline style masses were estimated as mg of protein using the method of Lowry et al. (1951), and a standard calibration curve for measuring protein was set up using bovine serum albumin (BSA). Enzyme activity was expressed in $\mathrm{mg}$ glucose $\mathrm{h}^{-1}$ per $\mathrm{mg}$ protein.

On Day 150 post-transplantation, Perna viridis was collected from each of the 4 experimental groups (KO, $\mathrm{MW}, \mathrm{KO} \rightarrow \mathrm{MW}, \mathrm{MW} \rightarrow \mathrm{KO}$ ). Shell length of each individual was measured to the nearest $0.01 \mathrm{~mm}$ using calipers. Ctenidial area was estimated by measuring the area of the ascending lamella of the outer demibranch, and palp area was estimated as the average of the surfaces of the right and left labial palps. Estimations of ctenidial and palp areas were made to the nearest $0.1 \mathrm{~mm}^{2}$, by measuring the outlines of magnified images obtained by a fixed high-resolution camera with a calibration scale (Leica Model: Quantimet $500+$ ) of relevant organs (excised from live mussels under a stereomicroscope and placed in a dish of seawater, allowing them to expand to a maximum extent, which occurred within a few minutes). This method was modified from the technique adopted by Jones et al. (1992) and Payne et al. (1995a). Both ctenidial and palp areas were measured in $\mathrm{mm}^{2}$. The ratio between palp area $(P)$ and ctenidial area $(C)$ was calculated as $P / C \times 100$ (Payne et al. 1995a).

Statistical analyses. Feeding responses and enzymatic activities among different groups were compared using 1 -way ANOVA followed by multiple-comparison procedures. The relationship between seston quantity and quality was analyzed by nonlinear regression. Linear regression was used in relating shell length and ctenidial and labial palp areas (log-transformed data), and elevations and intercepts of different regression lines were compared using ANCOVA. Since no significant differences were found for either initial or final shell length among the 4 experimental groups (see Fig. 4), no size standardization was conducted prior to between-group comparisons. Because a series of ANOVA or ANCOVA for variables that are not independent of each other were employed, a Bonferroni adjustment was used to correct for Type I errors, and significance for each ANOVA was evaluated against $\alpha=0.05$ divided by the number of comparisons being made (Sokal \& Rohlf 1995). All statistical methods used were according to Zar (1984).

\section{RESULTS}

\section{Hydrography of the 2 study sites}

Temporal variations in hydrographical parameters, including temperature, salinity, dissolved oxygen and food availability (TPM, POM, PIM, $f$ ), of the 2 experimental sites are shown in Fig. 2. Temperature changes at the 2 sites were similar, with low values in February and March and higher values in July and October (Fig. 2A). Salinity and dissolved oxygen values at Ma Wan, however, were consistently significantly lower than at Kat O (Fig. 2B,C). TPM and PIM concentrations were significantly higher $(t=-9.25, \mathrm{df}=295$, $\mathrm{p}<0.001$; and $t=-9.17$, df $=295, \mathrm{p}<0.001$, respectively) but organic content was significantly lower ( $t=$ 6.47, $\mathrm{df}=295, \mathrm{p}<0.001)$ at Ma Wan (TPM: 10.63 to $13.97 \mathrm{mg} \mathrm{l}^{-1}$; PIM: 6.79 to $10.51 \mathrm{mg} \mathrm{l}^{-1}, f: 0.22$ to 0.43 ) than at Kat O (TPM: 5.71 to $10.68 \mathrm{mg} \mathrm{l}^{-1}$; PIM: 3.60 to $6.21 \mathrm{mg} \mathrm{l}^{-1}, f: 0.38$ to 0.46 ) (Fig. 2D-G).

The organic fraction of seston was a negative power function of TPM for both sites, and the relationships were best described by the 2 equations shown in Fig. 3.

\section{Physiological measurements}

Both size groups of all treatments increased in length at the end of the experiment (Fig. 4), and mean shell 

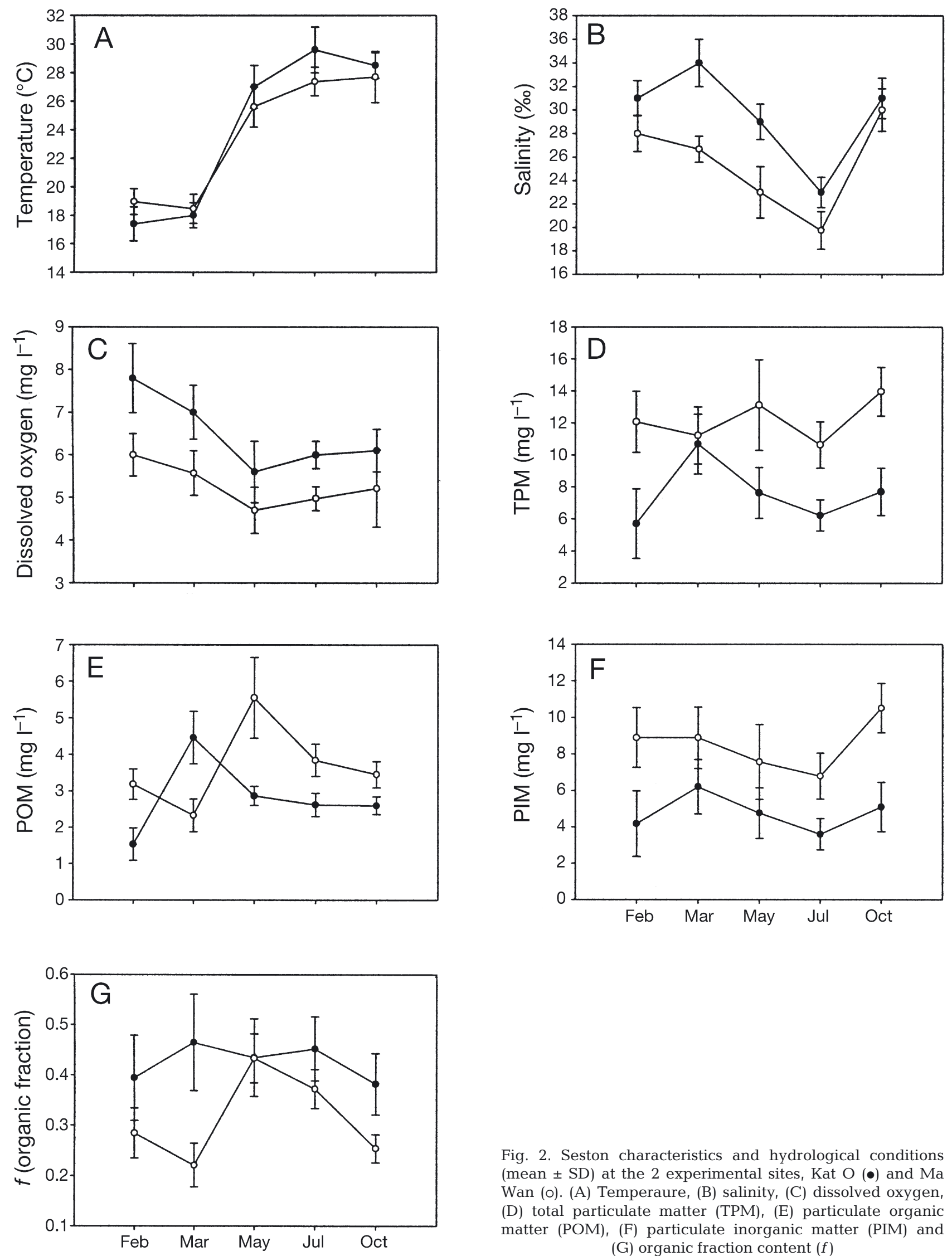

Fig. 2. Seston characteristics and hydrological conditions $($ mean $\pm \mathrm{SD})$ at the 2 experimental sites, Kat $\mathrm{O}(\bullet)$ and Ma Wan (o). (A) Temperaure, (B) salinity, (C) dissolved oxygen, (D) total particulate matter (TPM), (E) particulate organic matter (POM), (F) particulate inorganic matter (PIM) and (G) organic fraction content $(f)$ 

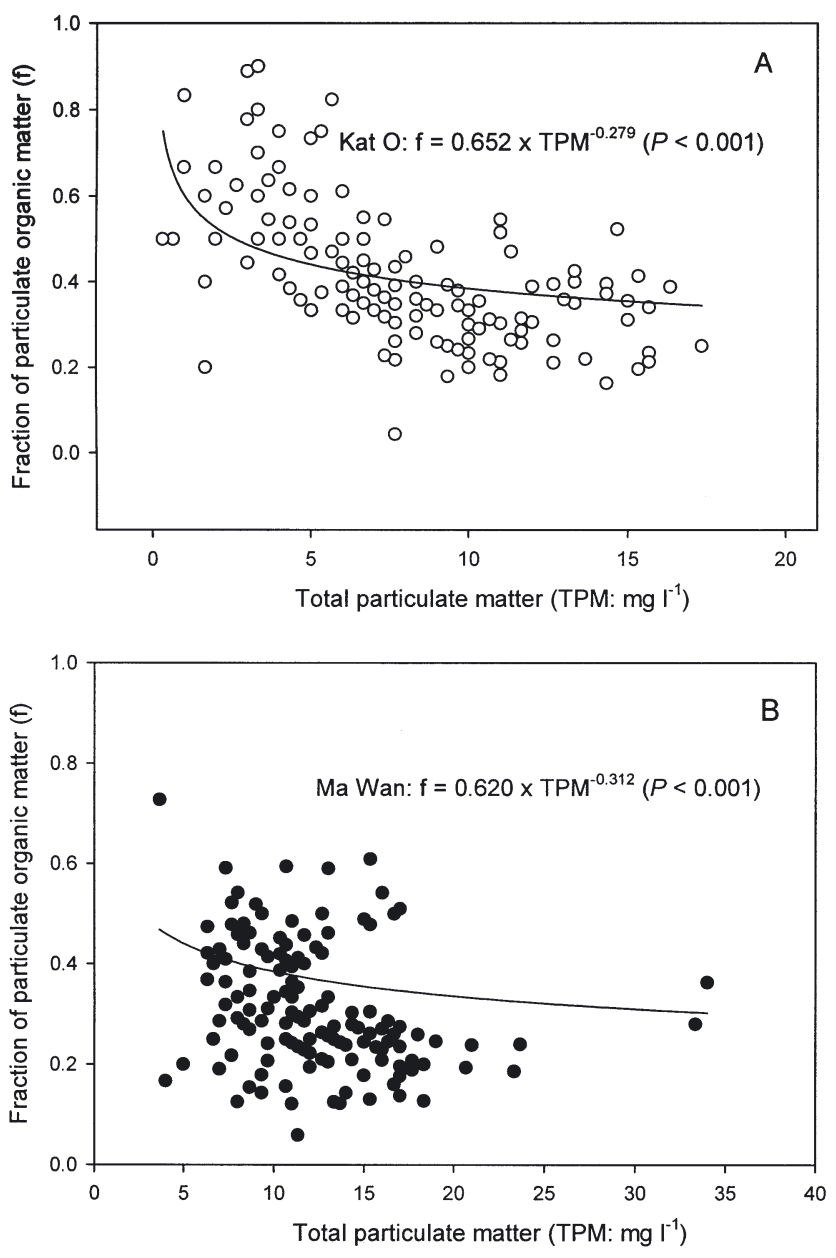

Fig. 3. Relationships between organic fraction content ( $f$ ) and total particulate matter (TPM) at the 2 experimental sites, (A) Kat $\mathrm{O}$ and (B) Ma Wan

length of S groups increased from ca. 35 to $65 \mathrm{~mm}$, and L groups from ca. 52 to $75 \mathrm{~mm}$. Differences in final length of the same size-group of different treatments, however, were insignificant for both small (1-way ANOVA, $F=1.67, \mathrm{df}=3,23, \mathrm{p}=0.20$ ) and large mussels (1-way ANOVA, $F=1.68, \mathrm{df}=3,24, \mathrm{p}=0.20$ ). No pseudofaeces were produced by individuals of KO and $\mathrm{MW} \rightarrow \mathrm{KO}$ throughout the experiment. MW individuals, however, produced pseudofaeces between all 5 visits (Fig. 5). For KO $\rightarrow$ MW, pseudofaeces were produced by all size groups on all occasions except for Group L individuals in May. Rejection rate of MW was significantly higher than that of $\mathrm{KO} \rightarrow \mathrm{MW}$. The difference, however, diminished as time elapsed. Clearance rate of the transplanted group of $\mathrm{MW} \rightarrow \mathrm{KO}$ was significantly lower than that of the native group KO, $\sim 10 \mathrm{~d}$ post-transplantation (Fig. 6), although the difference diminished as time elapsed. Clearance rate of $\mathrm{KO} \rightarrow \mathrm{MW}$, however, was comparable to that of MW throughout the experiment. Both native and transplanted individuals at Ma Wan had a consistently higher clearance rate than those at Kat O. Approximately $10 \mathrm{~d}$ post-transplantation, for the small mussels, the assimilation efficiency of transplanted individuals of $\mathrm{MW} \rightarrow \mathrm{KO}$ was lower than that of native individuals $(\mathrm{KO})$, while no difference was found between the transplanted $(\mathrm{KO} \rightarrow \mathrm{MW})$ and native (MW) mussels at Ma Wan (Fig. 7A). This difference, however, was diminished on Day 30 post-transplantation until the end of the experiment. For Group L, the difference in assimilation efficiency between native and transplanted individuals persisted almost throughout the experiment, especially for individuals cultured at Kat O (Fig. 7B). Similar to clearance rate, assimilation efficiency at Ma Wan was consistently higher than at Kat $\mathrm{O}$, for both native and transplanted individuals. Absorption rate of transplanted and native individuals was similar for both size groups (Fig. 8), with higher values being obtained at Ma Wan than at Kat O.

There was no significant difference in amylase and cellulase activity in the crystalline style and cellulase in the digestive diverticula between transplanted and native individuals at either site (Table 1). Amylase activity in the digestive diverticula of Perna viridis of $\mathrm{KO}$ and $\mathrm{MW} \rightarrow \mathrm{KO}$ was similar, whereas amylase activity of MW was either higher or similar to that of $\mathrm{KO} \rightarrow \mathrm{MW}$. Site-related differences in enzyme activity were observed, e.g. amylase activity in the digestive diverticula of small individuals of MW was higher than that of KO in May and October; such differences, however, were inconsistent.

ANCOVA showed significant differences in allometric relationships between shell length and palp

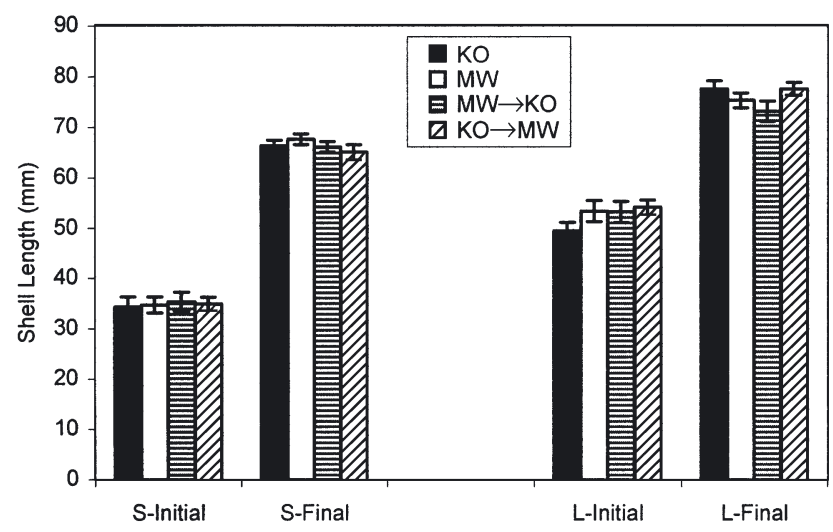

Fig. 4. Perna viridis. Initial and final shell length $( \pm \mathrm{SD})$ of the 4 experimental groups, $\mathrm{KO}$ (Kat O), MW $\rightarrow \mathrm{KO}$ (Ma Wan to Kat O transplant), MW (Ma Wan) and $\mathrm{KO} \rightarrow \mathrm{MW}$ (Kat O to Ma Wan transplant). S-Initial and S-Final, and L-Initial and L-Final mean initial and final measurements of small and large individuals $(\mathrm{N}=7)$ 

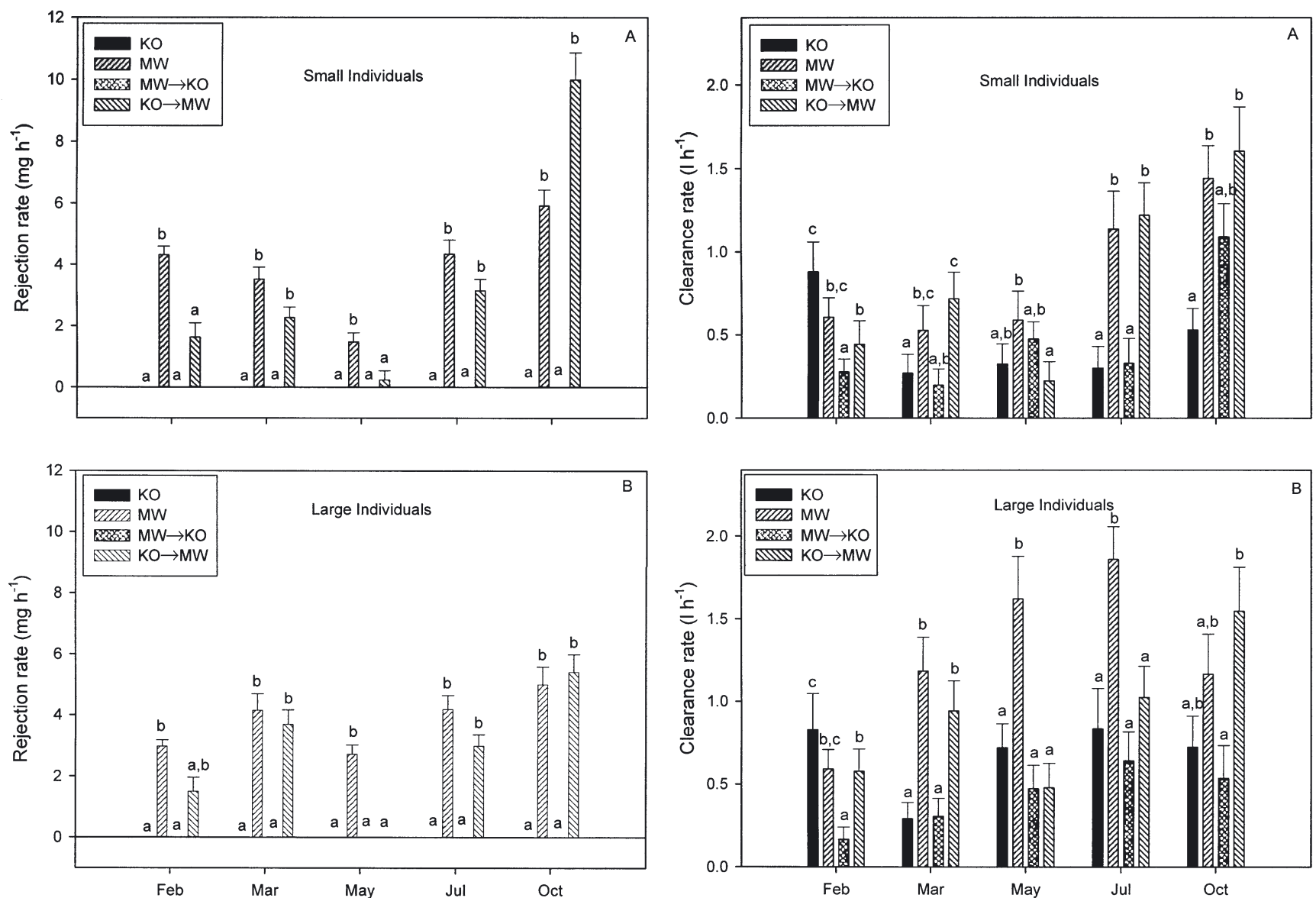

Fig. 5. Perna viridis. Rejection rate (RR: $\left.\mathrm{mg} \mathrm{h}^{-1}\right)( \pm \mathrm{SD})$ of $(\mathrm{A})$ small and (B) large individuals from February to October 1998 $(\mathrm{N}=7)$, of the 4 experimental groups, KO (Kat O) , MW (Ma Wan), MW $\rightarrow$ KO (Ma Wan to Kat O transplant) and $\mathrm{KO} \rightarrow \mathrm{MW}$ (Kat O to Ma Wan transplant). At each time point, treatmentmeans followed by different letters are significantly different $(p<0.005$ after Bonferroni adjustment)

Fig. 6. Perna viridis. Clearance rate $\left(\mathrm{CR}: \mathrm{l} \mathrm{h}^{-1}\right)( \pm \mathrm{SD})$ of $(\mathrm{A})$ small and (B) large individuals from February to October 1998 $(\mathrm{N}=7$ ), of the 4 experimental groups, KO (Kat O) , MW (Ma Wan), MW $\rightarrow$ KO (Ma Wan to Kat O transplant) and $\mathrm{KO} \rightarrow \mathrm{MW}$ (Kat O to Ma Wan transplant). At each time point, treatmentmeans followed by different letters are significantly different ( $p<0.005$ after Bonferroni adjustment)

area, but not between shell length and ctenidial area (Table 2). For regressions relating palp area and shell length, no difference was found among the slopes, but there was a significant difference in elevations between $\mathrm{KO}$ and MW, while the 2 transplanted groups did not show any difference to their original stocks $(\mathrm{MW} \rightarrow \mathrm{KO}$ vs $\mathrm{MW}$ and $\mathrm{KO} \rightarrow \mathrm{MW}$ vs $\mathrm{KO}$ ), or the stocks they were transplanted to (MW $\rightarrow \mathrm{KO}$ vs $\mathrm{KO}$ and $\mathrm{KO} \rightarrow \mathrm{MW}$ vs $\mathrm{MW}$ ). There was no significant relationship ( $\mathrm{p}>0.05)$ between the $P: C$ ratio and shell length for all 4 groups and, therefore, mean ratios were calculated for each one. The KO $P: C$ ratio was significantly higher than the other 3 groups (1-way ANOVA, p < 0.05). Differences between the native and transplanted groups at both sites, however, were not significant $(\mathrm{KO}=\mathrm{MW} \rightarrow \mathrm{KO}$, $\mathrm{MW}=\mathrm{KO} \rightarrow \mathrm{MW}$ ) (Table 3).

\section{DISCUSSION}

We found marked physiological differences (RR, CR, $\mathrm{AR}$ and $\mathrm{AE}$ ) between native groups of Perna viridis at Ma Wan and Kat $O$, with higher values being obtained for the former. Ma Wan is estuarine, with a significantly higher TPM concentration and lower organic content than Kat O. To cope with high seston levels, $P$. viridis growing at Ma Wan produced pseudofaeces: an adaptation for life within estuarine and shallow coastal habitats where seston levels are frequently high. By preferential rejection of inorganic matter as pseudofaeces, a degree of sorting is effected, by which material relatively enriched in organic content is selected for ingestion (Bayne 1993, Ward et al. 1997, Wong \& Cheung 1999). Bayne et al. (1993) estimated a $35 \%$ increase in the ingestion rate for POM over values 

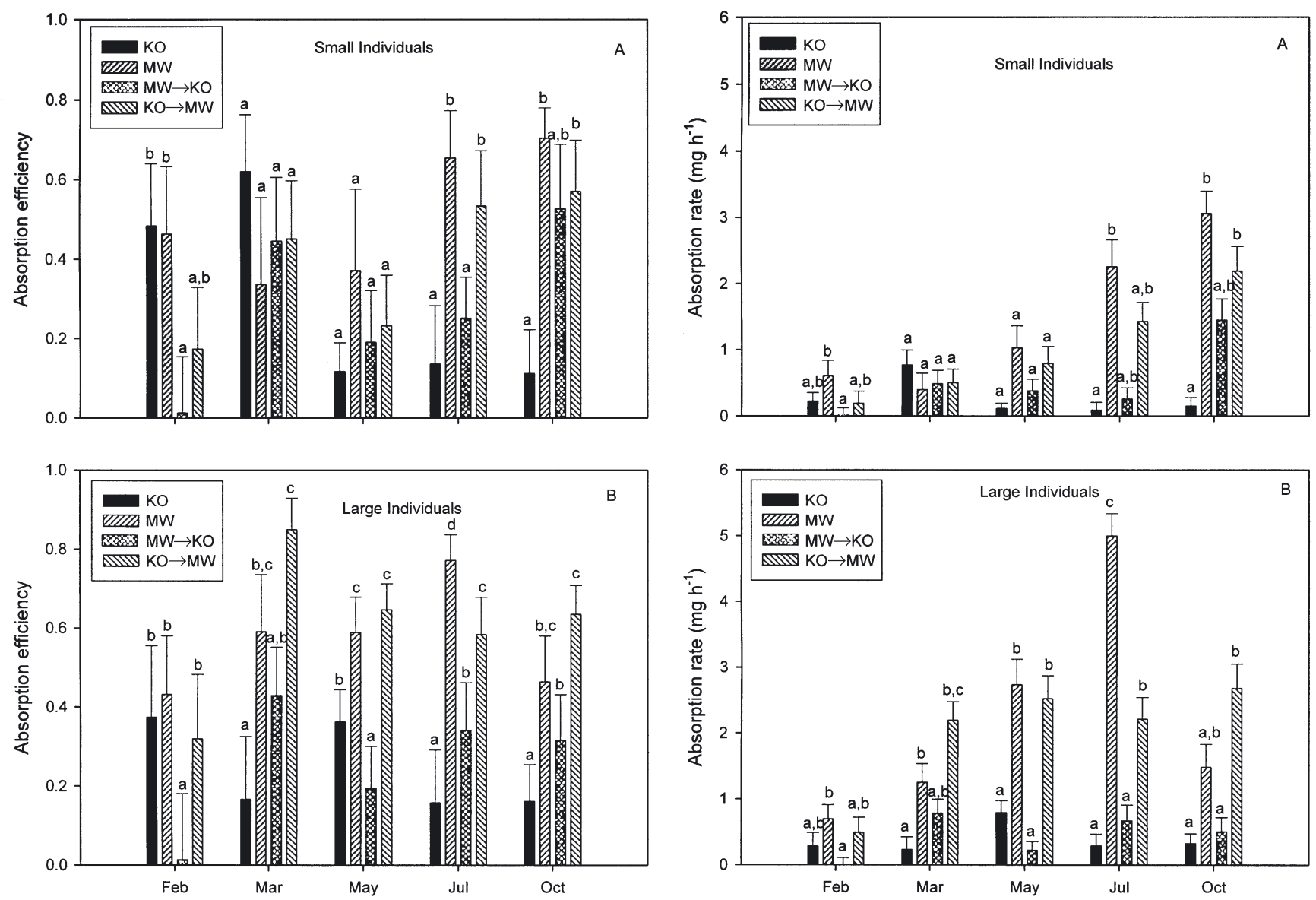

Fig. 7. Perna viridis. Absorption efficiency (AE) $( \pm \mathrm{SD})$ of (A) small and (B) large individuals from February to October $1998(\mathrm{~N}=7)$, of the 4 experimental groups, KO (Kat O), MW (Ma Wan), MW $\rightarrow$ KO (Ma Wan to Kat O transplant) and $\mathrm{KO} \rightarrow \mathrm{MW}$ (Kat $\mathrm{O}$ to Ma Wan transplant). At each time point, treatment-means followed by different letters are significantly different ( $\mathrm{p}<0.005$ after Bonferroni adjustment)

which would be expected if no compensation for reduced diet quality occurred. Such selection has been widely reported for temperate species such as Mytilus edulis and Cerastoderma edule (Ward et al. 1997, Hawkins et al. 1998b) and tropical species such as $P$. viridis and Pinctada margaritifera (Hawkins et al. 1998a). The production of pseudofaeces is commonly observed when a threshold concentration of TPM is reached (Bayne et al. 1976). This helps explain why both native and transplanted mussels cultured at Kat O did not produce pseudofaeces, as particulate concentrations at this site may be below the production threshold. Similar results were obtained in an annual study of feeding responses of $P$, viridis at Kat $\mathrm{O}$, of which pseudofaeces were produced only in 1 out of 12 mo (Wong \& Cheung 2001a). By ingesting all filtered particles, instead of selecting only nutritious

Fig. 8. Perna viridis. Absorption rate (AR: $\left.\mathrm{mg} \mathrm{h}^{-1}\right)( \pm \mathrm{SD})$ of (A) small and (B) large individuals from February to October $1998(\mathrm{~N}=7)$, of the 4 experimental groups, KO (Kat O), MW (Ma Wan), MW $\rightarrow$ KO (Ma Wan to Kat O transplant) and $\mathrm{KO} \rightarrow \mathrm{MW}$ (Kat $\mathrm{O}$ to Ma Wan transplant). At each time point, treatment-means followed by different letters are significantly different ( $p<0.005$ after Bonferroni adjustment)

ones, and producing pseudofaeces, energy intake by $P$. viridis could be maximized, although absorbed energy was still lower than that at Ma Wan, where POM concentration was much higher.

Transplanted individuals of Perna viridis acclimatized to their new environments within $1 \mathrm{mo}$, inter-site differences in physiological responses, therefore, were largely environmentally induced, i.e. phenotypic. The rate of acclimatization depends on a number of factors, and may be prolonged when environmental conditions differ markedly, or reproductive state differs (Worrall \& Widdows 1983). In a transplantation experiment between 3 populations of Scrobicularia plana, acclimatization was still incomplete after a transplant period of 3 mo (Worrall \& Widdows 1983). In contrast, rapid adaptation $(<6 \mathrm{wk})$ was shown by Mytilus edulis following reciprocal transplantation between 2 physio- 
Table 1. Perna viridis. Amylase activity and cellulase activity (mg glucose $\mathrm{h}^{-1} \mathrm{mg}$ protein ${ }^{-1}$ ) of each size group (S: small; L : large) from the 4 experimental groups, KO (Kat O) , MW (Ma Wan), MW $\rightarrow$ KO (Ma Wan to Kat O transplant) and KO $\rightarrow$ MW (Kat O to Ma Wan transplant) from May to October 1998. Note: within columns, treatment-means followed by different letters are significantly different ( $\mathrm{p}<0.0042$ after Bonferroni adjustment)

\begin{tabular}{|c|c|c|c|c|c|}
\hline & \multirow{2}{*}{ Groups } & \multicolumn{2}{|c|}{ _ Amylase } & \multicolumn{2}{|c|}{ Cellulase } \\
\hline & & $\mathrm{S}$ & $\mathrm{L}$ & $\mathrm{S}$ & L \\
\hline \multicolumn{6}{|l|}{ May } \\
\hline \multirow[t]{4}{*}{ Digestive diverticula } & $\mathrm{KO}$ & $3.65 \pm 0.40^{\mathrm{a}, \mathrm{b}}$ & $3.56 \pm 0.54^{\mathrm{a}, \mathrm{b}}$ & $1.46 \pm 0.28^{\mathrm{a}}$ & $2.15 \pm 0.47^{\mathrm{a}}$ \\
\hline & MW & $5.52 \pm 0.47^{b, c}$ & $6.02 \pm 0.61^{\mathrm{b}}$ & $1.92 \pm 0.33^{\mathrm{a}}$ & $1.79 \pm 0.36^{\mathrm{a}}$ \\
\hline & $\mathrm{MW} \rightarrow \mathrm{KO}$ & $2.64 \pm 0.48^{\mathrm{a}}$ & $2.58 \pm 0.36^{\mathrm{a}, \mathrm{b}}$ & $1.44 \pm 0.34^{\mathrm{a}}$ & $1.90 \pm 0.26^{\mathrm{a}}$ \\
\hline & $\mathrm{KO} \rightarrow \mathrm{MW}$ & $7.01 \pm 0.60^{c}$ & $2.12 \pm 0.42^{\mathrm{a}}$ & $3.90 \pm 0.34^{b}$ & $0.81 \pm 0.25^{\mathrm{a}}$ \\
\hline \multirow[t]{4}{*}{ Crystalline style } & $\mathrm{KO}$ & $2.38 \pm 0.20^{\mathrm{a}}$ & $2.01 \pm 0.24^{\mathrm{a}}$ & $1.52 \pm 0.24^{\mathrm{a}}$ & $1.32 \pm 0.18^{\mathrm{a}}$ \\
\hline & MW & $6.42 \pm 0.60^{a}$ & $6.55 \pm 0.72^{\mathrm{a}}$ & $1.41 \pm 0.37^{\mathrm{a}}$ & $1.51 \pm 0.45^{\mathrm{a}}$ \\
\hline & $\mathrm{MW} \rightarrow \mathrm{KO}$ & $2.00 \pm 0.53^{a}$ & $2.45 \pm 0.53^{\mathrm{a}}$ & $1.20 \pm 0.44^{\mathrm{a}}$ & $1.24 \pm 0.31^{\mathrm{a}}$ \\
\hline & $\mathrm{KO} \rightarrow \mathrm{MW}$ & $3.26 \pm 0.76^{\mathrm{a}}$ & $3.49 \pm 0.13^{\mathrm{a}}$ & $1.56 \pm 0.29^{\mathrm{a}}$ & $1.33 \pm 0.18^{\mathrm{a}}$ \\
\hline \multicolumn{6}{|l|}{ July } \\
\hline \multirow[t]{4}{*}{ Digestive diverticula } & $\mathrm{KO}$ & $4.93 \pm 0.48^{\mathrm{a}}$ & $3.78 \pm 0.44^{\mathrm{a}}$ & $4.00 \pm 0.40^{\mathrm{b}}$ & $3.27 \pm 0.35^{\mathrm{a}}$ \\
\hline & MW & $3.66 \pm 0.36^{\mathrm{a}}$ & $4.98 \pm 0.38^{\mathrm{a}}$ & $2.03 \pm 0.16^{\mathrm{a}}$ & $3.25 \pm 0.23^{\mathrm{a}}$ \\
\hline & $\mathrm{MW} \rightarrow \mathrm{KO}$ & $5.94 \pm 0.36^{a}$ & $5.12 \pm 0.35^{\mathrm{a}}$ & $3.43 \pm 0.27^{a, b}$ & $3.67 \pm 0.31^{\mathrm{a}}$ \\
\hline & $\mathrm{KO} \rightarrow \mathrm{MW}$ & $5.63 \pm 0.44^{\mathrm{a}}$ & $4.75 \pm 0.35^{\mathrm{a}}$ & $3.73 \pm 0.34^{\mathrm{b}}$ & $4.11 \pm 0.24^{\mathrm{a}}$ \\
\hline \multirow[t]{4}{*}{ Crystalline style } & $\mathrm{KO}$ & $5.07 \pm 0.73^{a}$ & $4.46 \pm 0.54^{\mathrm{a}}$ & $2.69 \pm 0.18^{\mathrm{a}}$ & $2.14 \pm 0.33^{a}$ \\
\hline & MW & $2.86 \pm 0.28^{\mathrm{a}}$ & $3.57 \pm 0.41^{\mathrm{a}}$ & $1.87 \pm 0.48^{\mathrm{a}}$ & $0.74 \pm 0.22^{\mathrm{a}}$ \\
\hline & $\mathrm{MW} \rightarrow \mathrm{KO}$ & $5.22 \pm 0.74^{\mathrm{a}}$ & $1.63 \pm 0.53^{\mathrm{a}}$ & $3.28 \pm 0.51^{\mathrm{a}}$ & $1.63 \pm 0.38^{\mathrm{a}}$ \\
\hline & $\mathrm{KO} \rightarrow \mathrm{MW}$ & $4.38 \pm 0.78^{\mathrm{a}}$ & $3.73 \pm 0.67^{a}$ & $2.16 \pm 0.35^{\mathrm{a}}$ & $2.09 \pm 0.38^{\mathrm{a}}$ \\
\hline \multicolumn{6}{|l|}{ October } \\
\hline \multirow[t]{4}{*}{ Digestive diverticula } & $\mathrm{KO}$ & $4.02 \pm 0.36^{\mathrm{a}}$ & $4.89 \pm 0.28^{\mathrm{a}, \mathrm{b}}$ & $1.91 \pm 0.22^{\mathrm{a}, \mathrm{b}}$ & $2.19 \pm 0.19^{\mathrm{a}}$ \\
\hline & MW & $7.89 \pm 0.56^{b}$ & $7.39 \pm 0.65^{\mathrm{b}}$ & $1.67 \pm 0.25^{\mathrm{a}, \mathrm{b}}$ & $1.87 \pm 0.24^{\mathrm{a}}$ \\
\hline & $\mathrm{MW} \rightarrow \mathrm{KO}$ & $4.12 \pm 0.28^{\mathrm{a}}$ & $3.79 \pm 0.27^{\mathrm{a}}$ & $2.04 \pm 0.14^{\mathrm{b}}$ & $2.23 \pm 0.29^{\mathrm{a}}$ \\
\hline & $\mathrm{KO} \rightarrow \mathrm{MW}$ & $4.16 \pm 0.37^{a}$ & $3.81 \pm 0.36^{\mathrm{a}}$ & $1.41 \pm 0.20^{\mathrm{a}}$ & $1.66 \pm 0.25^{a}$ \\
\hline \multirow[t]{4}{*}{ Crystalline style } & $\mathrm{KO}$ & $4.11 \pm 0.20^{\mathrm{a}}$ & $4.27 \pm 0.25^{\mathrm{a}}$ & $1.68 \pm 0.27^{\mathrm{a}}$ & $1.36 \pm 0.14^{\mathrm{a}}$ \\
\hline & MW & $3.07 \pm 0.57^{a}$ & $4.31 \pm 0.51^{\mathrm{a}}$ & $1.96 \pm 0.50^{\mathrm{a}}$ & $1.66 \pm 0.27^{\mathrm{a}}$ \\
\hline & $\mathrm{MW} \rightarrow \mathrm{KO}$ & $2.87 \pm 0.62^{\mathrm{a}}$ & $2.93 \pm 0.34^{\mathrm{a}}$ & $1.22 \pm 0.33^{\mathrm{a}}$ & $1.25 \pm 0.22^{\mathrm{a}}$ \\
\hline & $\mathrm{KO} \rightarrow \mathrm{MW}$ & $3.68 \pm 0.70^{a}$ & $2.83 \pm 0.70^{\mathrm{a}}$ & $1.64 \pm 0.47^{\mathrm{a}}$ & $1.55 \pm 0.25^{\mathrm{a}}$ \\
\hline
\end{tabular}

logically different populations (Widdows et al. 1984). The present study did not show any inter-site differences in acclimatization rates of feeding responses, with complete acclimatization being obtained $30 \mathrm{~d}$ post-transplantation. Complete acclimatization of amylase and cellulase activity in transplanted mussels was observed $90 \mathrm{~d}$ post-transplantation. As this was the first occasion post-transplantation when enzyme activities were determined, it is uncertain whether $90 \mathrm{~d}$ or a shorter period was required for complete acclimatization. Studies on other bivalves have shown that adjustment can take place in a short period of time. For example, the cellulase activity adjustment within the digestive diverticula is an acute $(3 \mathrm{~d})$ physiological response of the cockle Cerastoderma edule to increased food organic content (Ibarrola et al. 1996, 1998a). Bayne (1993) also pointed out that at least $15 \mathrm{~d}$ were required for the digestive system of $M$. edulis to significantly modify digestive-enzyme levels. Ibarrola et al. $(1998 \mathrm{a}, \mathrm{b})$ concluded that short-term digestive adjustments to seasonally changing food availability is a continuous process that determines the seasonal cycle of enzyme activities in the digestive diverticula of cockles. Apart from the effects of food on digestive enzyme activities, it was also found that specific cellulase and laminarinase activities in the digestive diverticula of cockles were correlated with the volumetric fraction of basophilic cells, and specific protease activity was highly correlated with lysosomal volume density (Ibarrola et al. 2000). This kind of digestive enzyme acclimation may also be influenced by other factors, such as temperature (Newell \& Branch 1980), salinity (Fang \& Chiou 1989) and pH (Sajiki \& Sato 1996).

The relative size of ctenidia and labial palps is another adaptation to the prevailing supply of suspended matter (Theissen 1982, Payne et al. 1995a,b). Bivalves usually have smaller ctenidial areas and larger palp areas in a siltier environment (Essink et al. 1989, Mettam 1992). Contrary to these studies, the native Perna viridis at Ma Wan, where suspended solid levels were higher, was characterized by a smaller 
Table 2. Perna viridis. Regression and comparison of palp and ctenidial areas of the 4 experimental groups, KO (Kat O), MW (Ma Wan), MW $\rightarrow$ KO (Ma Wan to Kat O transplant) and $\mathrm{KO} \rightarrow \mathrm{MW}$ (Kat O to Ma Wan transplant). Note: the $\alpha$-value for each regression line was 0.0063 after Bonferroni adjustment. Within columns, treatment means followed by different letters are significantly different ( $p<0.025$ after Bonferroni adjustment)

\begin{tabular}{|llcccccc|}
\hline \multirow{2}{*}{ Regressions } & \multirow{2}{*}{ Groups } & \multicolumn{5}{c}{ Linear regression $(y=\mathrm{ax}+\mathrm{b})$} \\
& & $\mathrm{a}$ & $\mathrm{b}$ & $\mathrm{n}$ & $\mathrm{R}^{2}$ & $\mathrm{p}$ \\
\hline Palp area (log) on & $\mathrm{KO}$ & 2.473 & $-2.734^{\mathrm{a}}$ & 14 & 0.600 & $<0.0063$ \\
shell length (log) & $\mathrm{MW}$ & 1.138 & $-0.453^{\mathrm{b}}$ & 18 & 0.707 & $<0.0063$ \\
& $\mathrm{KO} \rightarrow \mathrm{MW}$ & 2.247 & $-2.401^{\mathrm{a}, \mathrm{b}}$ & 19 & 0.661 & $<0.0063$ \\
& $\mathrm{MW} \rightarrow \mathrm{KO}$ & 2.247 & $-2.341^{\mathrm{a}, \mathrm{b}}$ & 14 & 0.669 & $<0.0063$ \\
& & & & & & \\
Ctenidial area (log) & $\mathrm{KO}$ & 2.278 & -1.663 & 14 & 0.869 & $<0.0063$ \\
on shell length (log) & $\mathrm{MW}$ & 2.354 & -1.795 & 18 & 0.829 & $<0.0063$ \\
& $\mathrm{KO} \rightarrow \mathrm{MW}$ & 1.762 & -0.709 & 19 & 0.833 & $<0.0063$ \\
& $\mathrm{MW} \rightarrow \mathrm{KO}$ & 1.804 & -0.787 & 14 & 0.884 & $<0.0063$ \\
\hline
\end{tabular}

palp:ctenidium ratio than the other group (KO). The discrepancy between the present study and those on other bivalves may be attributed to morphological differences in the feeding apparatus between $P$. viridis and other mytilids, in that the feeding apparatus of the former deviates significantly from the standard mytilid plan (Morton 1987). The dorsal edges of the outer and inner labial palps of $P$. viridis are united with the mantle or the visceral mass, respectively, for more than $2 / 3$ of their lengths, and both have only a small ventral sorting area, restricted to a thin line of ridges along the inner ventral margin. There are strong rejectory tracts in the mantle margins and on the visceral mass, resulting in relatively small ctenidial collection areas (Morton 1987). Palps in P. viridis, therefore, are assumed not to have such an important rejectory function as in other mytilids. Rather, the ctenidia and other organs of the mantle cavity are more important both in food acquisition and material rejection. Individuals of $P$. viridis growing in a siltier environment, therefore, should be expected to have a lower $P: C$ ratio, results which were in contrast to other bivalves (Table 3 ). This helps explain why a smaller $P: C$ ratio and higher feeding rates were obtained for individuals cultured at Ma Wan where the water is turbid. Given the fact that a significant change in ctenidium area, such as the $P: C$ ratio, occurred in $P$. viridis following transplantation from their original stocks (e.g. $\mathrm{KO} \rightarrow \mathrm{MW}$ close to $\mathrm{MW}$ but not $\mathrm{KO}$, see Table 3), relative palp size is suggested to be largely environmentally determined. Similar results were obtained for Mytilus edulis, in that after 4 mo transplantation, the relatively smaller ctenidia of Wadden Sea individuals did attain larger relative dimensions after being transferred to the low particle environment of the North Sea, and the larger relative ctenidium area of North Sea individuals decreased when transferred to the more turbid Wadden Sea (Essink et al. 1989).
The present study demonstrated that inter-site differences in growth of Perna viridis in Hong Kong, reported upon in previous studies, are largely attributed to food availability. A slower growth has been recorded for $P$. viridis at Tai Lam Chung in the western waters of Hong Kong (salinity: 19 to $31 \%$ ), as compared with Kat $\mathrm{O}$ in the east (salinity: 24 to $34 \%$ ), and was postulated to result from salinity stress and/or a poorer food quality due to dilution by the sediment, especially in summer (Lee 1986, Cheung 1991). Although both Ma Wan and Tai Lam Chung are located in western waters, the growth of $P$. viridis at Ma Wan was comparable to that at Kat $\mathrm{O}$ in the present study (Fig. 4). Clearance rate, absorption rate, and absorption efficiency were also higher at Ma Wan than at Kat O. Salinity, therefore, should not be a major factor limiting growth in P. viridis. Sundaram \& Shafee (1989) also reported that $P$. viridis could live well in salinities as low as $16 \%$. After acclimation to reduced salinity (as low as $13 \%$ ) for $44 \mathrm{~d}, M$. edulis was able to regulate shell growth independent of a wider range of salinities (Widdows 1985). Inter-site differences in growth of $P$. viridis in Hong Kong, therefore, are more likely caused by food availability. Laboratory experiments have demonstrated that particulate organic concentration is correlated with absorption rate in P. viridis (Wong \& Cheung 1999). Food availability was higher at Ma Wan and resulted in a higher POM concentration and organic content ( $f$ ) as compared with Tai Lam Chung, i.e. TPM at Ma Wan varied from 5.5 to $10.55 \mathrm{mg} \mathrm{l}^{-1}$ and $f$ varied from 0.2 to 0.43 , whereas TPM at Tai Lam Chung was similar (11.02 to $12.66 \mathrm{mg} \mathrm{l}^{-1}$ ) but $f$ was 25 to $40 \%$ lower $\left(0.15\right.$ to $0.26 \mathrm{mg} \mathrm{l}^{-1}$ ) than at Ma Wan. During summer and autumn, when growth of $P$. viridis was most rapid, $f$ at Tai Lam Chung could be as low as 0.06 to 0.13 (Cheung 1991). Although actual growth of $P$. viridis at Kat $\mathrm{O}$ and Ma Wan was comparable, the

Table 3. Perna viridis. Comparison of palp to ctenidial area $(P: C)$ ratio between the 4 experimental groups, $\mathrm{KO}$ (Kat O), MW (Ma Wan), MW $\rightarrow$ KO (Ma Wan to Kat O transplant) and $\mathrm{KO} \rightarrow \mathrm{MW}$ (Kat $\mathrm{O}$ to Ma Wan transplant). Note: values followed by different letters are significantly different $(p<0.05)$

\begin{tabular}{|lcl|}
\hline Groups & $n$ & $P: C$ ratio \\
\hline KO & 14 & $19.63^{\mathrm{b}}$ \\
MW & 18 & $15.62^{\mathrm{a}}$ \\
KO $\rightarrow$ MW & 19 & $15.18^{\mathrm{a}}$ \\
MW $\rightarrow$ KO & 14 & $17.21^{\mathrm{a}, \mathrm{b}}$ \\
\hline
\end{tabular}


discrepancy between absorption rate and true growth may be due to mucus production from large pallial glands (Morton 1987). Excessive mucus production may cause a net loss of carbon, and this was most clearly observed when animals were fed diets with a low organic content (Prins \& Smaal 1989). Urrutia et al. (2001) suggested that underestimation of 'true' rates of organic ingestion and absorption of dietary organic matter in Cerastoderma edule may be as high as 46 and $98.6 \%$, respectively, as a result of the assumption that the presence of mucus in the pseudofaeces is negligible. Davies \& Hawkins (1998) estimated that 1 to $68 \%$ of the energy consumed may be expended on mucus production in molluscs. A relatively larger quantity of mucus was produced in the present study as a result of high PIM concentration in the seston at Ma Wan. In contrast, Kat O was characterized by low TPM and high $f$-values, and energy loss through mucus secretion, therefore, should be lower (Wong \& Cheung 2001a).

The data of our reciprocal transplantation experiment showed that differences in feeding physiology of Perna viridis between 2 experimental sites in Hong Kong with contrasting hydrographies were mainly induced by environmental factors. Complete acclimatization of the physiological responses of transplanted mussels was demonstrated $30 \mathrm{~d}$ posttransplantation and that of morphology, in terms of palp area and $P: C$ area ratio, was demonstrated $150 \mathrm{~d}$ post-transplantation. The acclimatization of this species becomes more ecologically important with its recent invasion into many other areas world wide (Ingrao et al. 2001). The invasions of exotic bivalves into other water bodies have resulted in major reorganizations in planktonic and benthic communities (Carlton \& Geller 1993). In San Francisco Bay, USA, for example, the invasion of the clam Potamocorbula amurensis was associated with the decline in abundance of 3 common estuarine copepod species, probably owing to the consumption of naupliar stages (Kimmerer et al. 1994). Therefore, it can be predicted that the invasiveness of the green mussel $P$. viridis and its adaptation to new environments can bring potential impacts to those aquatic ecosystems, and studies on population dynamics, and its consequence to the water columns of this species, should be monitored continuously.

Acknowledgements. We thank B. P. Kelaher and B. Morton for their constructive comments on earlier drafts of the manuscript of this paper. Three reviewers are also appreciated in helping to improve the quality of this manuscript, particularly the suggestions on statistical analysis. This research was supported by a studentship to W.H.W. from the School of Graduate Studies, City University of Hong Kong.

\section{LITERATURE CITED}

Bayne BL (1993) Feeding physiology of bivalves: timedependence and compensation for changes in food availability. In: Dame RF (ed) Bivalve filter feeders in estuarine and coastal ecosystem processes. NATO ASI Series, Vol G 33. Springer-Verlag, Berlin, p 1-24

Bayne BL, Newell RC (1983) Physiological energetics of marine molluscs. In: Saleuddin ASM, Wilbur KM (eds) The Mollusca, Vol 4. Academic Press, New York, p 407-515

Bayne BL, Thompson RJ, Widdows J (1976) Physiology: I. In: Bayne BL (ed) Marine mussels: their ecology and physiology. Cambridge University Press, Cambridge, p 121-206

Bayne BL, Iglesias JIP, Hawkins AJS, Navarro E, Héral M, Deslous-Paoli JMD (1993) Feeding behaviour of the mussel, Mytilus edulis: responses to variations in quantity and organic content of the seston. J Mar Biol Assoc UK 73: 813-829

Carlton JT, Geller JB (1993) Ecological roulette: the global transport of nonindigenous marine organisms. Science 261:78-82

Chalermwat K, Lutz RA (1989) Farming the green mussel in Thailand. World Aquacult. 20:41-46

Chan IKK (1992) Phosphoglucose isomerase (PGI) selection in the green mussel, Perna viridis (L.). In: Aldrich JC (ed) Quantified phenotypic responses in morphology and physiology, Proc 27th Eur Mar Biol Symp. JAPAGA, Ashford, p 15-24

Cheung SG (1991) Energetics of transplanted populations of the Green-lipped mussel Perna viridis (Linnaeus) (Bivalve: Mytilacea) in Hong Kong. I: Growth condition and reproduction. Asian Mar Biol 8:117-131

Crisp DJ (1971) Energy flow measurements. In: Holme NA, Mcintyre AD (eds) Methods for the study of marine benthos. International Biological Programme 16. Blackwell Scientific Publication, Oxford, p 197-279

Davies MS, Hawkins SJ (1998) Mucus from marine molluscs. Adv Mar Biol 34:1-71

Essink K, Tydeman P, de Koning F, Kleef HL (1989) On the adaptation of the mussel Mytilus edulis L. to different environmental suspended matter concentration. In: Proc 21st Eur Mar Biol Symp. Polish Academy of SciencesInstitute of Oceanology, Gdansk, p 41-51

Fang LS, Chiou SF (1989) Effect of salinity on the activities of digestive proteases from the tilapia fish, Oreochromis niloticus in different culture environments. Comp Biochem Physiol A 93:439-443

Guo X, Ford SE, Zhang F (1999) Molluscan aquaculture in China. J Shellfish Res 18:19-31

Hawkins AJS, Simth RFM, Tan SH, Yasin ZB (1998a) Suspension-feeding behaviour in tropical bivalve molluscs: Perna viridis, Crasssostrea belcheri, Crassostrea iradelei, Saccostrea cucculata and Pinctada margaritifera. Mar Ecol Prog Ser 166:173-185

Hawkins AJS, Bayne BL, Bougrier S, Héral M, Iglesias JIP, Navarro E, Smith RFM, Urrutia MB (1998b) Some general relationships in comparing the feeding physiology of suspension-feeding bivalve molluscs. J Exp Mar Biol Ecol 219:87-103

Huang ZG, Lee SY, Mak PMS (1985) The distribution and population structure of Perna viridis (Bivalvia: Mytilacea) in Hong Kong waters. In: Morton B, Dudgeon D (eds) Proc 2nd Int Workshop Malacofauna of Hong Kong and Southern China. Hong Kong University Press, Hong Kong, p 465-471

Ibarrola I, Iglesias JIP, Navarro E (1996) Differential absorp- 
tion of biochemical components in the diet of the cockle Cerastoderma edule: enzymatic responses to variations in seston composition. Can J Zool 74:1887-1897

Ibarrola I, Larretxea X, Iglesias JIP, Urrutia MB, Navarro E (1998a) Seasonal variation of digestive enzyme activities in the digestive gland and the crystalline style of the common cockle Cerastoderma edule. Comp Biochem Physiol 121A:25-34

Ibarrola I, Navarro E, Iglesias JIP (1998b) Short-term adaptation of digestive processes in the cockle Cerastoderma edule exposed to different food quantity and quality. J Comp Physiol 168B:32-40

Ibarrola I, Etxeberria M, Iglesias JIP, Urrutia MB, Angulo E (2000) Acute and acclimated digestive responses of the cockle Cerastoderma edule (L.) to changes in food quality and quantity II. Enzymatic, cellular and tissular responses of the digestive gland. J Exp Mar Biol Ecol 252:181-198

Iglesias JIP, Urrutia MB, Navarro E, Alvarez-Jorna P, Larretxea X, Bougrier S, Héral M (1996) Variability of feeding processes in the cockle Cerastoderma edule (L.) in response to changes in seston concentration and composition. J Exp Mar Biol Ecol 197:121-143

Ingrao DA, Mikkelsen PM, Hicks DW (2001) Another introduced marine mollusk in the Gulf of Mexico: the IndoPacific green mussel, Perna viridis, in Tampa Bay, Florida. J Shellfish Res 20:13-19

Jones HD, Richards OG, Southern TA (1992) Gill dimensions, water pumping rate and body size in the mussel Mytilus edulis L. J Exp Mar Biol Ecol 155:213-237

Kautsky N, Johannesson K, Tedengren M (1990) Genotyptic and phenotypic differences between Baltic and North Sea populations of Mytilus edulis evaluated through reciprocal transplantations. 1. Growth and morphology. Mar Ecol Prog Ser 59:203-210

Kimmerer WJ, Gartside E, Orsi JJ (1994) Predation by an introduced clam as the likely cause of substantial declines in zooplankton of San Francisco Bay. Mar Ecol Prog Ser 113:81-93

Lee SY (1986) Growth and reproduction of the Green mussel Perna viridis (L.) (Bivalvia: Mytilacea) in contrasting environments in Hong Kong. Asian Mar Biol 3:111-127

Lowry OH, Rosebrough NJ, Farr AL, Randall RJ (1951) Protein measurements with the Folin phenol reagent. J Biol Chem 193:265-275

Mettam C (1992) Changing palp morphology of Mytilus edulis along a gradient of turbidity. In: Aldrich JC (ed) Quantified phenotypic responses in morphology and physiology. Proc 27th Eur Mar Biol Symp. JAPAGA, Ashford, p 229-237

Morton B (1987) The functional morphology of the organs of the mantle cavity of Perna viridis (Linnaeus, 1758) (Bivalvia: Mytilacea). Am Malacol Bull 5:159-164

Morton B, Morton JE (1983) The sea shore ecology of Hong Kong. Hong Kong University Press, Hong Kong

Navarro E, Iglesias JIP (1993) Infaunal filter-feeding bivalves and the physiological response to short-term fluctuations in food availability and composition. In: Dame RF (ed) Bivalve filter feeders in estuarine and coastal ecosystem processes. NATO ASI Series, Vol G 33. Springer-Verlag, Berlin, p 25-56

Nelson N (1944) A photometric adaptation of the Somogyi method for the determination of glucose. J Biol Chem 153: 375-380

Newell RC, Branch GM (1980) The influence of temperature on the maintenance of metabolic energy balance in marine invertebrates. Adv Mar Biol 17:329-396
Okumus I, Stirling HP (1994) Physiological energetics of cultivated mussel (Mytilus edulis) populations in two Scottish west coast sea lochs. Mar Biol 119:125-131

Payne BS, Lei J, Miller AC, Hubertz ED (1995a) Adaptive variation in palp and gill size of the Zebra mussel (Dreinsena polymorpha) and Asian clam (Corbicula fluminea). Can J Fish Aquat Sci 52:1130-1134

Payne BS, Miller AC, Lei J (1995b) Palp to gill area ratio of bivalves: a sensitive indicator of elevated suspended solids. Regul Rivers Res Manag 11:193-200

Prins TC, Smaal AC (1989) Carbon and nitrogen budgets of the mussel Mytilus edulis L. and the cockle Cerastoderma edule (L.) in relation to food quality. Sci Mar 53: $477-482$

Riget F, Johansen P, Asmund G (1997) Uptake and release of lead and zinc by blue mussels: experience from transplantation experiments in Greenland. Mar Pollut Bull 34: 805-815

Riisgård HU (1977) On measurements of the filtration rates of suspension feeding bivalves in a flow system. Ophelia 16: 167-173

Sajiki J, Sato M (1996) Effects of acids and storage temperatures on the phospholipase A activities in oyster digestive glands. Jpn J Toxicol Environ Health 42:333-339

Seed R, Richardson CA (1999) Evolutionary traits in Perna viridis (Linnaeus) and Septifer virgatus (Wiegmann) (Bivalvia: Mytilidae). J Exp Mar Biol Ecol 239:273-287

Siddall SE (1980) A clarification of the genus Perna (Mytilidae). Bull Mar Sci 30:858-870

Sokal RR, Rohlf FJ (1995) Biometry: the principles and practice of statistics in biological research. WH Freeman, San Francisco

Somogyi M (1952) Notes on sugar determination. J Biol Chem 195:19-23

Sundaram KS, Shafee MS (1989) Salinity tolerance of some bivalves of Ennore Estuary. J Mar Biol Assoc India 31: 299-302

Tedengren M, André C, Johannesson K, Kautsky N (1990) Genotyptic and phenotypic differences between Baltic and North Sea populations of Mytilus edulis evaluated through reciprocal transplantations. 3. Physiology. Mar Ecol Prog Ser 59:221-227

Teo LH, Sabapathy U (1990) Preliminary report on the digestive enzymes present in the digestive gland of Perna viridis. Mar Biol 106:403-407

Theissen BF (1982) Variation in size of gills, labial palps and adductor musscle in Mytilus edulis L. (Bivalvia) from Danish waters. Ophelia 21:49-63

Urrutia MB, Navarro E, Ibarrola I, Iglesias JIP (2001) Preingestive selection processes in the cockle Cerastoderma edule: mucus production related to rejection of pseudofaeces. Mar Ecol Prog Ser 209:177-187

Ward JE, MacDonald BA (1996) Pre-ingestive feeding behaviors of two sub-tropical bivalves (Pinctada imbricata and Arca zebra): responses to an acute increase in suspended sediment concentration. Bull Mar Sci 59:417-432

Ward JE, Levinton JS, Shumway SE, Cucci T (1997) Site of particle selection in a bivalve mollusc. Nature 390:131-132

Widdows J (1985) The effects of fluctuating and abrupt changes in salinity on the performance of Mytilus edulis L. In: Gray JS, Christiansen ME (eds) Proc 18th Eur Mar Biol Symp, Oslo, Norway. John Wiley, New York, p 555-566

Widdows J, Donkin P, Salkeld PJ, Cleary JJ, Lowe DM, Evans SV, Thomson PE (1984) Relative importance of environmental factors in determining physiological differences between two populations of mussels (Mytilus edulis). Mar Ecol Prog Ser 17:33-47 
Wong WH, Cheung SG (1999) Feeding behaviour of the green mussel, Perna viridis (L.): responses to variation in seston quantity and quality. J Exp Mar Biol Ecol 236: 191-207

Wong WH, Cheung SG (2001a) Feeding rates and scope for growth of green mussels, Perna viridis (L.) and their relationship with food availability in Kat O, Hong Kong. Aquaculture 193:123-137

Wong WH, Cheung SG (2001b) Feeding rhythms of the green-lipped mussel, Perna viridis (Linnaeus, 1758) (Bivalvia: Mytilidae) during spring and neap tidal cycles. J Exp Mar Biol Ecol 257:13-36

Wong WH, Cheung SG (2003) Seasonal variation in the feed-

Editorial responsibility: John Lawrence (Contributing Editor), Tampa, Florida, USA ing physiology and scope for growth of green mussels, Perna viridis (L.) in estuarine Ma Wan, Hong Kong. J Mar Biol Assoc UK 83:543-552

Worrall CM, Widdows J (1983) Physiological changes following transplantation of the bivalve Scrobicularia plana between three populations. Mar Ecol Prog Ser 12: 281-287

Yukihira H, Klumpp DW, Lucas JS (1999) Feeding adaptations of the pearl oysters Pinctada margaritifera and $P$. maxima to variations in natural particulates. Mar Ecol Prog Ser 182:161-173

Zar JH (1984) Biostatistical analysis. Prentice Hall, Englewood Cliffs, NJ

Submitted: September 3, 2002; Accepted: June 9, 2003 Proofs received from author(s): August 18, 2003 